This work is licensed under a Creative Commons Attribution 4.0 International License.

Ovaj rad dostupan je za upotrebu pod međunarodnom licencom Creative Commons Attribution 4.0.

\title{
MORFOLOGIJA, SINTAKSA I LEKSIK GLAGOLJSKOGA INVENTARA SAMOSTANA SV. MARIJE MAGDALENE U PORTU NA OTOKU KRKU (1734. - 1878.)
}

dr. sc. Sandra Požar, Staroslavenski institut, sudec@stin.hr, Zagreb

izvorni znanstveni članak

UDK 003.349.1(210.7Krk)

rukopis primljen: 17. listopada 2019; prihvaćen za tisak: 5. prosinca 2019.

Članak opisuje jezik Inventara samostana sv. Marije Magdalene u Portu na otoku Krku (1734. - 1878.), spomenika praktične pismenosti franjevaca trećoredaca glagoljaša. Prikazuju se morfološke osobitosti u Inventaru, sintaktičke značajke vezane uz atribut kao najzastupljeniju sintaktičku kategoriju u tekstu i slavenski leksički elementi. Na morfološkoj razini uočava se utjecaj južnijih čakavskih dijalektnih elemenata, što se nastavlja na inodijalektne utjecaje u fonologiji.

Ključne riječi: glagoljica; franjevci trećoredci glagoljaši; praktična glagoljska pismenost; povijest hrvatskoga jezika; čakavsko narječje; govori otoka Krka

\section{Uvod}

Inventar samostana sv. Marije Magdalene u Portu na otoku Krku pisan je kurzivnom glagoljicom i, manjim dijelom, latinicom od 1734. do 1878. godine u portanskom samostanu sv. Marije Magdalene franjevaca trećoredaca. Ta je inventarna knjiga, kao spomenik praktične pismenosti franjevaca trećoredaca glagoljaša, u prvom redu izvor podataka o povijesti redovničke 
zajednice franjevaca trećoredaca u Hrvatskoj i o lokalnoj povijesti otoka Krka. U inventarnim se popisima svakih nekoliko godina nabraja samostanski inventar ovim redoslijedom: crkva, sakristija, kuhinja, blagovaonica, konoba, samostan, a tim je prostorima dodana kategorija ljetine i blaga (intrada). Inventar je kodikološki opisao V. Štefanić (1960), a njegov je tekst u latiničnoj transkripciji objavio A. Badurina (2013). U članku Požar (2018b) prikazane su grafijske, ortografske i glasovne pojave Inventara. Taj članak pokazao je kako je opća fonološka slika Inventara, osobito njegova starijega dijela, podudarna s opisom doseljeničkih krčkih govora u literaturi (Lukežić, Turk 1998; Milčetić 1895). Međutim, utvrđena je i nekonzistentnost podataka zbog neujednačenosti i variranja kod pojedinih fonoloških pojava: refleksâ jata, popratnih samoglasnika uz slogotvorno $r$ i kod skupine čr/cr (usp. Požar 2018b: 34-37). Osim toga, u mlađem dijelu Inventara zabilježene su jugoistočnije čakavske značajke koje međutim nisu potkrijepljene dolaskom govornika s toga područja (usp. Botica, Kovačić, Kuhar 2015: 29-45). Tim se osobitostima pridružuju neke od morfoloških značajka prikazanih u nastavku, koje su pridonijele blagu rastakanju jezične slike Inventara. ${ }^{1}$

\section{Morfologija i morfosintaksa}

\subsection{Imenske riječi}

\subsubsection{Sklonidba}

Zbog naravi i namjene teksta imenske su riječi daleko bolje potvrđene od glagola. Od padeža je osim nominativa obaju brojeva najbolje potvrđen genitiv množine, što je očekivano s obzirom na narav teksta, budući da taj padež služi kao dopuna broju. Kao nastavak genitiva množine najčešći je nulti nastavak, ali to se sa sigurnošću može utvrditi samo za ženski rod, odnosno za e-deklinaciju, npr. žlic, zdil (22r). Po potrebi je u suglasničku

1 Potvrde koje se navode preslovljene su kao u izdanju Badurina (2013), postupkom transliteracije s elementima transkripcije (znak jat prenosi se kao je ili ja, derv kao j, šta kao šć ili ć). Grafijska je posebnost Inventara mogućnost bilježenja glasa /j/ i mekoće suglasnika /l/ i /n/ okomitom crticom iznad retka, što je u izdanju preneseno apostrofom. Od Badurinina se postupka odstupa u dva slučaja. Prvo, u izdanju je transkripcija jata označena kurzivom (sljedovi je i ja), a u ovom je članku to zanemareno jer bi - budući da se u njemu ne obrađuju grafija i fonologija - nepotrebno štetilo preglednosti. Druga iznimka učinjena je pri obradi leksika u odjeljku 4, gdje je transkripcija još više fonetizirana, pa su tako palatalno /í/ i /ń/, koji se u glagoljici uobičajeno pišu kao $L$ i $N$, preneseni kao lj i nj. 
skupinu kojom osnova završava umetnut sekundarni samoglasnik: dasak (6r), bačav (22v), lokarad (62v). Muški je rod u genitivu množine problematičan. Naime, za nulti nastavak nema potvrde, nego je pravilo nastavak $-i{ }^{2}$ Međutim, taj je nastavak homoniman s nastavkom nominativa množine, pa nije uvijek sigurno o kojem je padežu riječ. Nesigurnosti pridonosi i to što i pridjevski atributi mogu imati takav završetak ili biti međusobno nesročni, odnosno u dvama različitim padežima. Da je načelno riječ o nominativu, daje naslutiti ženski rod, usp. mriže popone bolih i gorih (15r). Isto tako, na nominativ upućuje pridjevski oblik, npr. noži veliki 2 $(14 v)$, paramenti mostirski (28v). No i ovdje se može utvrditi neujednačenost, pa se tako u neposrednoj blizini (unutar nekoliko redaka) susreću smjene nominativnih, genitivnih i miješanih sintagma, npr. noži veliki $2(14 \mathrm{v})$, mihi starih $6(14 \mathrm{v})$; paramenti mostirski od svile dobrih 11 / paramenti mostirski od svile stari 〈11〉 1 (28v); pijati beli velikih use 11 . pijati sridnih beli use 3 / pijati malih beli use 26 . pijati kositernih veli use 9 (43r).

Nedvojbeni je nastavak genitiva množine muškoga roda a-deklinacije nastavak -ov: mihov (1r, 6r, 8v); tavajolov (68r b), svidrov (68v a), štramacov, kavicalov, štrapuntinov, karpaturov, šugamanov, lancunov (70r a); tavajolov, karatelov (71r a); šugamanov, lancunov, parov, inštrumentov $(72 \mathrm{v} b)$; istrumentov $(78 \mathrm{v} \mathrm{b)}$, koji međutim nije svojstven lokalnomu govoru (usp. Lukežić, Turk 1998: 203). ${ }^{3}$ Ako se zanemari nekoliko potvrda s početka Inventara, nastavak -ov pojavljuje se od stranice $68 \mathrm{r}$ b, od godine 1790., iako ne u svim potvrdama genitiva. Razlog je pojavljivanju oblika $s$ nastavkom -ov, budući da ga u dubašljanskom govoru nema ni danas, očito izvanjezični. No, kako je već napomenuto, razlog se ne može tražiti u činjenici doseljenja redovnika koji nisu bili krčkoga podrijetla (usp. Botica, Kovačić, Kuhar 2015: 29-45). Umjesto toga može se pomišljati na osviještenost pojedinih pisara o široj uporabi hrvatskoga jezika i jezičnostandardizacijskim tendencijama, što je na tragu ideje o nacionalnoj svijesti pisarâ koju je iznio I. Botica istražujući jedan drugi izvor franjevačke glagoljske praktične pismenosti: Knjige posinovljenja, novicijata i zavjetovanja franjevaca trećoredaca glagoljaša otoka Krka (Botica, Kovačić, Kuhar 2015). Naime, Botica idejom nacionalne svijesti objašnjava naoko paradoksalnu činjenicu da se Dragutin Antun Parčić, poznat kao svećenik glagoljaš i

\footnotetext{
2 Tako je i u Milčetić 1895: 119.

3 To je još jedna jugoistočnija čakavska crta; na kvarnerskom prostoru nije zabilježena sjevernije od Svetoga Jakova na sjeveru otoka Lošinja (Milčetić 1895: 118; 119).
} 
obnovitelj crkvenoslavenskoga jezika u rimskoj liturgiji, ${ }^{4} \mathrm{u}$ praktične dnevne svrhe služio latinicom. Osvrćući se na Parčićev latinični zapis povodom završetka novicijata i polaganja redovničkih zavjeta, Botica među ostalim navodi: „Vlastoručni Parčićev zapis otkriva nacionalno svjesnoga pojedinca i preporoditelja koji se hrvatskim latiničnim zapisom izdvajao od ostalih u svojoj redovničkoj zajednici." (Botica, Kovačić, Kuhar 2015: 13). ${ }^{5}$ Na pitanje zašto bi se pisari trudili učiniti tekst funkcionalnijim na širem hrvatskom jezičnom prostoru odgovor može biti vrlo praktičan: da bi dokument lakše mogla provjeriti za to zadužena mjerodavna osoba iz trećoredske Provincije.

Uz navedene nastavke u iznimnim je slučajevima u muškom rodu potvrđen genitiv množine s pridjevskim nastavkom, npr. pijatih mali 24 $(25 \mathrm{v})$, što ne treba nužno proglasiti pogreškom jer se ta pojava može pronaći i drugdje u dijalektima (usp. primjerice suvremeni kajkavski).

Ostali su češće potvrđeni padežni oblici: genitiv jednine e-deklinacije -e (Mikule $4 \mathrm{r}$, trate $8 \mathrm{v}$, štampe $12 \mathrm{v}$, svile $21 \mathrm{v}$, mere $64 \mathrm{v}$, štente $80 \mathrm{v} \mathrm{b}$ ); akuzativ množine a-deklinacije -i (težaki 33r); instrumental jednine a-deklinacije -om/ -em (dilom 2r, s telcem 31v); instrumental jednine e-deklinacije -u ( $z^{\prime}$ muštru čarnu 24v); nominativ množine a-deklinacije -i (pijati, lopiži 54r); nominativ množine e-deklinacije -e (žlice, bačve $54 \mathrm{v}$ ); instrumental množine a-deklinacije -i (z merli 12r); instrumental množine e-deklinacije -ami (z' buštami 13v).

Potvrđen je kratki oblik pridjeva: vina nemirena (20v), od bela vina (30r), vina cila (31v), mesa suha (79r a), kao i sklonidba brojeva: od dvih libric (57r), svić od trih unač (9v); s' trimi ključi (14v), s trimi kluči (27r), s telci dvimi (51r). Broj 'četiri' sačuvan je u starijem obliku četire koji je međutim izjednačen za muški i ženski rod: ba(ri)li četire (15v), koze četire (1v). Pridjevski nastavak u genitivu razlikuje tvrdu i meku inačicu -oga/-ega: mezanoga (4v), deblega (14r), ali ne u stranim riječima, usp. deveršoga (40v).

U sklonidbi pridjeva i brojeva opaža se značajka doseljeničkih krčkih govora da je nastavak nominativa množine u srednjem rodu jednak ženskomu (usp. Lukežić, Turk 1998: 202; 234): sito gusto 1 . a retke usve sita $2(8 \mathrm{v})$, rakna kolorane (10v), sedla stare harvaske $2(15 \mathrm{r})$, rakna bele (...) $n^{\circ} 14$ (23r), rakna stare usve $n^{\circ} 1$, vesla dobre $n^{\circ} 3(23 \mathrm{v})$, rakna bele bole i gore use 6 $(41 v)$, sedla stare $d v i(44 r)$. No treba spomenuti da se u kasnijem dijelu

4 Opsežna analiza toga Parčićeva projekta donesena je u disertaciji V. Blažević Krezić (Blažević Krezić 2016).

5 Parčićev zapis v. u Botica, Kovačić, Kuhar 2015: 140. 
Inventara (od godine 1798.) pojavljuje i nastavak za srednji rod podudaran imeničnomu: sedla stara (73r, 75r, 77r a, 79r b).

\subsubsection{Padežni sinkretizam}

U Inventaru se susreću padežni sinkretizmi koji na više načina homonimiziraju oblike za izražavanje različitih padežnih značenja. Neki su tipovi sinkretizma slavenski, a neki upućuju na romanski utjecaj.

Uz uobičajen općehrvatski genitivno-akuzativni sinkretizam na račun akuzativa u jednini imenica $a$-deklinacije treba navesti da je on u korpusu moguć i u množini. Potvrđen je kod pridjeva pri elipsi imenice: za mrtvih (12v), za mertvih (17r, 21v), za ubozih (74v b, 78v b), za ubogih (76v a). Množinski genitivno-akuzativni sinkretizam, kao izraz kategorije živosti, u čakavskom je posredno poznat i od starijih vremena zahvaljujući utjecaju toga idioma koji je sačuvan u crkvenoslavenskom jeziku (usp. Vince 2014: 97-98). ${ }^{6}$ U jednini je sinkretizam u korpusu potvrđen i kod zamjenice koja se odnosi na neživo, usp. križ S(ve)toga Mikule od srebra, koga uzeše prokaratur (11v).

Kao rezultat intenzivna i dugotrajna dodira s romanskim idiomima čest je akuzativno-lokativni sinkretizam na račun lokativnoga oblika tipičan za inovativne doseljeničke govore (Lukežić, Turk 1998: 208, 229-230), uz prijedloge u i na, npr. kamenice za ule u konobu (8v), škrin u kamare (23r). ${ }^{7}$

I ovdje se bilježi smjenjivanje oblika u bliskom susjedstvu, primjerice zamjeničkih pridjeva: na istomu (...) oltar S(veto)ga Mikula od brašćine / na isti (...) na isti (...) na isti (...) (67v a).

\subsubsection{Posebnosti zamjenica}

Pokazna zamjenica drugoga stupnja pokaznosti u starijem je dijelu Inventara analoški ujednačena s ostalima: oti (prema ovi, oni), npr. i z otim dva pavunaci $(9 \mathrm{v}, 12 \mathrm{v})$, što nije krčka značajka (usp. Lukežić, Turk 1998: 166; 189; 210; 231), nego južnija čakavska (usp. Lisac 2009: 152).

6 Istraživši imenske gramatičke kategorije u hrvatskom crkvenoslavenskom jeziku, J. Vince je utvrdila: „Općenito vrijedi da je kategorija živosti to izraženija što je tekst noviji, udaljeniji od oltara i pod snažnijim čakavskim utjecajem." (Vince 2014: 98).

7 Više takvih primjera navedeno je u Požar 2018a: 297. O romanskom utjecaju na rasap paradigme usp. Lukežić, Turk 1986. 
U novijem dijelu Inventara, od 1786. godine, pojavljuje se odnosna riječ što: što izručuje na stranicama 62v, 67v, 70v, 72r, 73v, 75v, 77v, 79v, što bi trebalo upućivati na pojavljivanje redovnika neotočnoga podrijetla: ne nužno štokavskoga, nego jugoistočnijega čakavskog, gdje ima utjecaja štokavštine. Međutim, povijesni izvori, kako je navedeno gore, to ne potvrđuju. Može se pretpostaviti da se, budući da je riječ o ustaljenoj formuli („inventar koji izručuje A B-u"), nakon prve dvije unesene potvrde (iz 1786. i 1790.) taj oblik uspostavio kao norma i dalje prenosio (uz iznimku čto 75v, 1804.). Druga je mogućnost da to bude još jedan argument $u$ korist onomu što je navedeno $u$ odjeljku 2.1.1. u vezi s nastavkom genitiva množine -ov: da je riječ o upoznatosti sa širom uporabom hrvatskoga jezika.

\subsection{Glagoli}

Jedini bolje potvrđeni glagolski oblik jest infinitiv. Pojavljuje se i sa završnim - $i$ i bez toga završetka, pri čemu je prva mogućnost neusporedivo rjeđa, pa se mogu navesti sve potvrde: soliti (1r), poiti (1r), peći $(9 \mathrm{v}, 40 \mathrm{v}, 66 \mathrm{v}$ a), držati (10v), klečati $(12 \mathrm{r})$, sijati $(30 \mathrm{v}, 53 \mathrm{v}, 54 \mathrm{v}, 60 \mathrm{v})$, prositi $(31 \mathrm{r})$, stroiti (31r, 37r), rizati (55r), učiti (55v) kalati (63v, 66v a, 68r a), nositi (64v), prati (66v a, 69r b, 76r a). Posljednja potvrda infinitiva na -i (soliti, $78 \mathrm{v}$ a) potječe s početka 19. stoljeća. $^{8}$

Budući da je u korpusu neokrnjeni oblik infinitiva u povlačenju, to pruža priliku da se razmotre okolnosti njegova nestanka. Kao čimbenik koji bi mogao utjecati na uporabu okrnjenoga infinitiva uočava se red riječi, odnosno redoslijed glagola i objekta, te njegov odraz na rečeničnu intonaciju. Naime, ako je objekt ispred glagola, tada je naglašen jer je red riječi obilježen, a to se posljedično možda moglo odraziti na oblik infinitiva, usp. škravade za peći oštie (9v), gradele za peći ribu (40v), kade za soliti meso (78v a) škravade za oštie peć (29r), škare za ovce strić (15r), badnić za broskvu kisat (18r), bat za kamiki batit (18v). Ima potvrda gdje je infinitiv krnj i u neobilježenom redu riječi: dižica za črpat vino (8r), mihi za prosit vino (37r), mina za mirit žito (50r), osti za ribarit ribu (52v). No obrnuti slučajevi - gdje bi neokrnjeni infinitiv bio u postpoziciji - nisu zabilježeni. Stoga ovi slučajevi mogu upućivati na to odakle počinje tendencija uporabe krnjega oblika, ili barem što ju potpomaže.

8 Taj popis nije datiran, a priređivač je pretpostavio da je riječ o 1806. godini (Badurina 2013: 171). Nije naodmet podsjetiti da se do kraja 19. stoljeća završno -i u infinitivu potpuno izgubilo na ovom području; Milčetić ga bilježi samo na Silbi (Milčetić 1895: 128). 
Ostali se glagolski oblici pojavljuju rijetko ili vrlo rijetko. Među prezentskim oblicima pažnju privlači oblik počimle, karakterističan za jugoistočni čakavski prostor. Taj se oblik pojavljuje u drugom dijelu Inventara (od stranice $47 \mathrm{v}, 1777$.$) , a od stranice 70 \mathrm{v}$ (1794.) potpuno prevladava nad oblikom počinje.

U vezi s izricanjem prošloga vremena može se spomenuti živost aorista i imperfekta, npr. bi mirena (2r), rekoh (21r), bi naprošeno (51r); bihu razverženi (26v), potezahu (2r), što još i danas odlikuje ovaj model govora, barem kad je riječ o imperfektu (usp. Lukežić, Turk 1998: 216). ${ }^{9}$ Imperfekt je potvrđen i kod svršenih glagola: križ (...) koga uzeše prokaratur (11v), prižuntahu (25r), umriše gvardijan pasani (52v). Od ostalih vremena potvrđen je perfekt: bil je špolan $(79 \mathrm{v}$ a), te futur: oboe razbieno da hote načinit $(12 r) .{ }^{10}$

\section{Sintaksa}

$\mathrm{Na}$ sintaksu Inventara bitno utječe narav i namjena teksta. One određuju njegov stil, koji se s jedne strane može smatrati administrativnim; odnosno zbog nepotpune ustaljenosti obrazaca - još ga je bolje nazvati predadministrativnim. S druge je strane stil obilježen praktičnom namjenom, te stoga ima i značajke razgovornoga jezika. Sintaksa je zbog naravi teksta najbolje potvrđena u kategoriji atributa, pa se opis usredotočuje na njegove osobitosti.

\subsection{Red riječi}

\subsubsection{Položaj atributa}

Administrativni stil dolazi do izražaja u položaju atributa u odnosu na imenicu. Kako inventariziranje uključuje nabrajanje, a katkad i razvrstavanje, važno je da se predmet najprije imenuje, a zatim da se pobliže opiše i odredi, i to tako da se navede njegova precizna količina ili mjera te da ga se po potrebi razvrsta. Stoga je atribut najčešće postponiran imenici, i to ne samo nesročni - kojemu je ondje mjesto i u neobilježenom redu riječi nego i sročni, npr. rubi od platna za stol dobrih (8r), cingul od svile cerleni

\footnotetext{
9 Usp. i Milčetić 1895: 127.

$10 \mathrm{U}$ dijelu knjige gdje se nalaze odredbe o vođenju inventarnih knjiga pronađena je još jedna potvrda futura: biti hoće drugi inventarii (102v), ali i drugih glagolskih oblika: futura II. (pokle švaršen bude 102v) i imperativa (da bude zapisana 102v, ima biti svaršeno i inventarijano 102v).
} 
(28v), zdil velih od darva (29v), stol veli i banci okolo / stol mali od oriha (41r), jidro za brod staro 'edno (41v); kamiži mostirski od platna finoga i z merli rakamani 1 / kamiži mostirski od platna mezanoga mostirskih dobrih 3 (28v). Kao što pokazuju primjeri, redoslijed je sročnoga i nesročnoga atributa u odnosu na imenicu promjenljiv.

\subsubsection{Red riječi u atributu}

U atributu koji se se sastoji od konstrukcije za + glagolska skupina koja se sastoji od infinitiva i njegove dopune (objekta) moguć je i neobilježen red riječi, glagol + objekt, i obilježen red riječi, objekt + glagol; usp. mihi za prosit vino (37r), škare za ovce strić (15r).

Čini se da je u ovom slučaju povod obilježenomu redu riječi spontanost. Naime, izrazu koji je već sam po sebi dovoljno obavijestan naknadno se - da se učini još jasnijim - dodaje glagol. Radnja se dodanoga glagola zbog asocijativne veze između imenica u subjektu i objektu podrazumijeva, pa je glagol zališan ili u najmanju ruku nije neophodan; usp. škare za ovce (strić) 15r, badnić za broskvu (kisat) 18r, bat za kamiki (batit) 18v, škravade za oštie (реć) $29 r$.

Iz navedenoga u 3.1.1. i 3.1.2. može se zaključiti da je red riječi u Inventaru uvjetovan dvjema suprotnim tendencijama: jedna je nužna administrativnost koja prati ovakvu vrstu dokumenata, a drugu čine spontanost i obilježja razgovornoga jezika tijesno povezana uz praktičnu pismenost.

\subsection{Sročnost $s$ brojevima}

Brojevi dva, tri i četiri slažu se s nominativom množine. Potvrđeni su brojevi dva i četiri: $z$ otim 2 . pavunaci (9v), facoli dva novi od svile beli (29r), ulija barili 4 . sići 4 incirka (23v).

\subsection{Nesročnost pridjevskoga atributa}

Mjestimično zabilježena nesročnost pridjevskoga atributa s imenicom može se tumačiti na dva načina. Jedna je mogućnost romanski utjecaj, odgovoran i za rasap paradigme. Međutim, sasvim je zamislivo i prihvatljivo tumačiti da je nesročnost u skladu s administrativnim, ali i razgovornim stilom. Naime, predmet je - radi preglednosti - imenovan nominativom, a genitivom se izražava njegovo dodatno određenje, $s$ obzirom na to da se predmeti broje, npr. kamenice za ul'e usve velikih $n^{\circ} 3$ (23r), mriže proste bolih i gorih (23v). 


\subsection{Konstrukcije u atributima}

Općeproširena konstrukcija koja se uobičajeno tumači kao sintaktički kalk potaknut talijanskim utjecajem jest konstrukcija $z a+$ infinitiv, odnosno $z a+$ glagolska skupina, npr. mihi za prosit vino (37r). ${ }^{11}$ Rezultat je talijanskoga poticaja i prijedložni izraz s prijedlogom $o d .^{12}$

Kao specifičnost pojavljuje se socijativna konstrukcija s veznikom $i$. Riječ je o nepravom instrumentalu društva koji M. Ivić u monografiji o instrumentalu naziva pseudosocijativ (Ivić 1954). Ta se kategorija smatra ovdje primjerenom jer se potvrde tiču neživih ili neobosobljenih referenata:

1) železo ki stoi na ogn'išće i svoim kavadunom (53v)

2) gaeta i svoiom potribom (56r)

3) brod i svoim armižem (79r b)

4) krava ka e' doma is telcem (31v)

5) kobila i ždribicom ( $77 \mathrm{r}$ a). ${ }^{13}$

I ovdje je moguće tumačenje da je riječ o spontanosti u pisanju i razgovornom stilu, što rezultira zalihošću. No treba razmotriti i drugo tumačenje jer su u jezičnoj povijesti potvrđene takve konstrukcije koje su podrijetlom vrlo stare. M. Ivić (1954: 184-194) tu podvrstu socijativa naziva kategorijom „cjeline” jer predmet izražen instrumentalom čini cjelinu s drugim članom socijativnoga izraza, a tipičan je takav primjer odnos majke i djeteta, odnosno životinje i mladunčeta, kao u potvrdama (4) i (5). Značenje je takva izraza „zastupničko”: nadređeni član na neki način zastupa podređenoga. To je tipično u vladarskim ispravama, usp. primjerice: A tomu daru bêše svêdoci dobri Bošnjane: tepčija Radoslav i s bratjom, knez Dabiša i s bratjom (1340, Stjepana Kotromanića listine Vukosavu

11 Više primjera vidi u Požar 2018a: 298. Treba uzeti u obzir i tumačenje koje je ponudio J. Vela (2019), da je riječ o unutarnjem jezičnom razvoju, ili pak paralelnom arealnom razvoju, i uz to dodati da u ovakvim slučajevima, gdje je konstrukcija za + infinitiv atribut, možda bolje nego igdje drugdje dolazi do izražaja glagolskoimenička narav odnosno podrijetlo infinitiva. Međutim, s obzirom na sveprisutan i dugotrajan romanski utjecaj na području o kojem je ovdje riječ, treba računati barem s talijanskim poticajem ovoj pojavi.

12 Potvrde i njihovo razvrstavanje po značenju vidi u Požar 2018a: 299.

13 U svim je potvrdama osim u (4) prijedlog s/z stegnut s početkom sljedeće riječi, a to je uobičajeno i drugdje u korpusu (usp. Požar 2018b: 39). 
Hrvatiniću; Ivić 1954: 189). ${ }^{14}$ Autorica naglašava veliku starinu „zastupničkih" konstrukcija, tvrdeći da odražavaju indoeuropsko shvaćanje podređenosti kao svojevrsne pripadnosti. Nakon 15. stoljeća ne nalazi potvrdâ. Bi li ovdje navedeni primjeri bili kasnije potvrde te stare konstrukcije, ostaje za daljnje istraživanje.

\subsection{Atributne rečenice}

Atribut se u Inventaru mjestimice izražava odnosnom rečenicom, koja može biti uvedena dvjema vrstama odnosnih riječi: odnosnom zamjenicom $k i$, koja se sklanja ( 1 - 6) i nepromjenljivom odnosnom riječju (relativizatorom) ča $(7,8)$, a obje su mogućnosti uobičajene u sintaksi slavenskih odnosnih rečenica (usp. Minlos 2012).

1) kolonica na koi stoji kašeta za lemuzinu (12r)

2) junčić ki pase doma z' voli (15v)

3) banki na kih se kleči (45r)

4) krava (...) u koi e del četerti od mostira (51r)

5) kopanice u kih se čini kruh (54v)

6) voli s kimi se ore, kon' ki e za mostir (62r)

7) sikire ča duperaju junaci (50r)

8) sira mirena ča bi naprošeno do sad (51r).

Primjetno je da se odnosna riječ u (7) i (8) pojavljuje bez resumptivne zamjenice (lične zamjenice u određenom padežu), što je tipično i za suvremene nestandardne jezične varijetete. ${ }^{15}$ Stoga se ta pojava može smatrati još jednom značajkom razgovornoga stila u Inventaru, koja je mogla biti potpomognuta i okrnjenom paradigmom.

\footnotetext{
14 Potvrda bi te kategorije mogla biti i početna rečenica drugoga dijela Bašćanske ploče: $\mathrm{Az}$ opat Dobrovit zdah crekav siju i svojeju bratiju s devetiju, tj. može se pretpostaviti da je u njoj prijedlog stegnut (s svojeju), a dodatno se instrumentalni izraz udvaja zbog navođenja broja (s devetiju).

15 Usp. Mihaljević, Polančec 2016, gdje autori pokazuju da se resumptivna zamjenica u nestandardnim idiomima ispušta ako je antecedent nešto neživo.
} 


\section{Leksik}

Inventar je vrijedan izvor za povijesnu terminologiju, a termini koje obuhvaća mogu se podijeliti po područjima s obzirom na djelatnosti samostana. Leksik Inventara pokazuje znatnu zastupljenost romanizama koji potječu iz različitih jezičnih i vremenskih slojeva. Najzastupljeniji su venecijanizmi, a dosta je i dalmatskih leksičkih ostataka, dok su ostali romanski elementi tek sporadični. Venecijanizmi pokrivaju ove leksičke skupine: crkveni namještaj, liturgijska oprema (namještaj, pribor, ruho i tkanine), kuhinjski predmeti (pribor za jelo i kuhanje), namještaj i kućni uporabni predmeti, pomorstvo (dijelovi i oprema broda, vrste ribarskih mreža). Većina dalmatskih leksičkih ostataka odnosi se na kućanstvo. Budući da su romanizmi opisani (Požar 2018a: 300-307), ovdje se analizira slavenski leksik i upućuje se na stupanj njegove zastupljenosti u odnosu na romanizme.

Slavenski su leksemi, u skladu s tradicionalnim oblicima privređivanja, najzastupljeniji u leksičkom polju koje obuhvaća pojmove vezane uz poljoprivredu, a prikazani su u tablici $1 .^{16}$

Tablica 1. Slavenski leksemi vezani uz poljoprivredu

\begin{tabular}{|l|l|}
\hline posuđe & $\begin{array}{l}\text { dižica 'drvena posuda s ručkom za prelijevanje vina', kabal } \\
\text { 'kabao', kamenica 'posuda za ulje', otakač 'niski široki kabao u } \\
\text { koji se toči vino iz bačve', rešeto, sito }\end{array}$ \\
\hline oruđe i pribor & $\begin{array}{l}\text { bat, glavina 'središnji dio kotača', hrasnica 'motika ravna sječiva', } \\
\text { karčica 'motika za razbijanje gruda zemlje', kosica 'mala kosa', } \\
\text { kosir 'oruđe za košnju slično srpu', lemeš 'dio pluga', majkača } \\
\text { 'motika za poravnavanje zemlje nakon oranja', mih 'mijeh', } \\
\text { motika, pila, ralica 'malo ralo' (Skok, s.v. orati), serp/sarp 'srp', } \\
\text { sikira 'sjekira', svidar 'svrdlo', tesla 'vrsta sjekire', veruge 'lanci', } \\
\text { voz 'kola'(?), vrganj 'oralo koje razgrće zemlju', vuk 'sprava za } \\
\text { navlačenje obruča na bačve', zub 'oruđe za dubljenje kamena'(?) } \\
\text { (za dubat kamiki) }\end{array}$ \\
\hline
\end{tabular}

16 Značenja se navode, ako nije drugačije napomenuto, prema popisu manje poznatih riječi u izdanju (Badurina 2013: 207-212). Značenje se ne navodi za lekseme koje imaju podudarno značenje u hrvatskom standardnom jeziku. 


\begin{tabular}{|l|l|}
\hline $\begin{array}{l}\text { poljoprivredne } \\
\text { kulture, } \\
\text { proizvodi i } \\
\text { postupci }\end{array}$ & $\begin{array}{l}\text { bob, dvoredac 'ječam'(?), leća, meso, muka 'brašno', ozimac } \\
\text { 'ječam', proso, slanina, sočivo 'mahunarke', šenica; } \\
\text { termini za vino: cilo, ne posve cilo, vodenica 'razvodnjeno vino', } \\
\text { (vino) zvaštano 'ukiseljeno'; } \\
\text { ophati 'otući, oljuštiti tučenjem' }\end{array}$ \\
\hline stočarstvo & $\begin{array}{l}\text { bravarija 'davanje ovaca u najam', opaša 'grlo za ispašu', opašni } \\
\text { 'za ispašu'(?), oratni (o volu) 'za oranje', (janci na) sužan 'zalog', } \\
\text { samac 'mužjak', samica 'ženka', škopac 'kastrirani ovan' }\end{array}$ \\
\hline
\end{tabular}

Nekoliko navedenih leksema zahtijeva tumačenje ili napomenu. Podrijetlo leksema kabao neki autori smatraju germanskim (usp. Skok, s.v. kabao). Leksem hrasnica P. Skok povezuje uz kras (Skok, s.v. kras). Leksem majkača, koji nije zabilježen ni u Rječnik 1880-1976. ni u Skokovu etimološkom rječniku, može se vjerojatno dovesti u vezu s glagolom mahati, imajući na umu pokret pri razgrtanju zemlje. Podrijetlo leksema zvaštan (o vinu) nije posve jasno, ali možda bi se moglo dovesti u vezu s glagolom izvečati, izvedenom od osnove pridjeva vetah 'star' (usp. Skok, s.v. izvečati). $\mathrm{U}$ vezi s glagolom ophati treba dodati da takav, prefigirani oblik glagola pahati W. Boryś povezuje uz vrbnički govor (Boryś 2007: 185). U vezi s leksemom bravarija treba napomenuti da mu je slavenska samo osnova, odnosno da je hibridna izvedenica, što je zanimljivo u kontekstu jezičnih dodira. Uz leksem sužan treba dodati da bi mogla biti riječ i o toponimu Sužan, koji postoji na otoku Krku, i to u okolici Dobrinja (usp. Spicijarić Paškvan 2014b: 355, bilj. 8). ${ }^{17}$

Slavenski leksemi prevladavaju jedino u navedenim područjima. U drugim leksičkim poljima zastupljeni su u osjetnoj manjini u odnosu na romanizme. Prikazani su u tablici 2.

17 Slično kao što se na drugom mjestu u Inventaru, u istom kontekstu spominjanja lokaliteta ispaše ovaca i janjaca, pojavljuje krčkorumunjski toponim Šugare (usp. Požar 2018a: 193). 
Tablica 2. Slavenski leksemi vezani uz ostala leksička polja

\begin{tabular}{|c|c|}
\hline kućanstvo & $\begin{array}{l}\text { bilac 'vuneni pokrivač', popečak ‘žarač za vatru', ponjava } \\
\text { 'deblji pokrivač', postilja 'krevet', slamnica/slavnica } \\
\text { 'slamarica za krevet', verč 'vrč', vrića 'vreća' }\end{array}$ \\
\hline $\begin{array}{l}\text { kuhinja } \\
\text { (pribor, } \\
\text { posuđe i } \\
\text { ostalo) }\end{array}$ & $\begin{array}{l}\text { kalić 'posuda za otpatke', klišća 'kliješta', konj ‘stalak na } \\
\text { ognjištu', kopanjica 'drveno korito', kuharica 'kuhača', } \\
\text { kuhinja, lonac, nož, ognjišće 'ognjište', pinica 'žlica za } \\
\text { uklanjanje pjene', ražanj, stargulja 'ribež', šupljača ‘šuplja } \\
\text { žlica', zdela 'zdjela', žlica }\end{array}$ \\
\hline $\begin{array}{l}\text { crkvena } \\
\text { oprema i } \\
\text { liturgijski } \\
\text { pribor }\end{array}$ & $\begin{array}{l}\text { ispovidalnica 'ispovjedaonica', kadilnik 'kadionica', } \\
\text { kropilnica 'škropionica', propelce 'raspelo', rub 'oltarnik; } \\
\text { stolnjak (u blagovaonici)', stalnica 'stalak za uskrsnu } \\
\text { svijeću; uskrsna svijeća', škravade 'kliješta za pečenje } \\
\text { hostija' }\end{array}$ \\
\hline pomorstvo & $\begin{array}{l}\text { brod, jidro 'jedro', kopitnjak 'vrsta mreže za školjke', osti, } \\
\text { plav 'brod', prosta/prostica 'vrsta mreže', svitilo 'svjetilo' }\end{array}$ \\
\hline
\end{tabular}

Treba se osvrnuti na problematičan leksem škravade, kojemu slavensko podrijetlo nije očito, a ni sigurno, iz glasovnoga sastava jer početna distribucija škr-i završetak -ada asociraju na romansko podrijetlo (usp. Skok, s.v. skrovada '1. plitka tepsija s drškom'; furlansko podrijetlo; usp. i venecijanizam scrova, koji međutim ima potpuno neodgovarajuće značenje: 'krmača'; Boerio 1867, s.v. scroa). Dvojbenosti između romanskoga i slavenskoga podrijetla pridonosi i podatak da rumunjski jezik ima leksem scovardă 'palačinka ili slično jelo od tijesta koje se priprema u tavi' koji se smatra slavenskom posuđenicom (Mihăilă 1960: 60, 242). Odgovor na pitanje o podrijetlu može dati podrobniji opis imenovanoga predmeta. Kada bi bila riječ o šupljikavoj (rešetkastoj) površini, podrijetlo bi se tumačilo romanski, kao što je slučaj s hrvatskom otočkom toponimijom. ${ }^{18}$ No budući da je riječ o dvjema metalnim pločama koje su povezane pomičnim dijelom, podsjećajući na dvije spojene tave, podrijetlo se može smatrati slavenskim. U tom slučaju leksem naime potječe od praslavenskoga *sk(o)vorda; usp. staroslavenski skovrada 'tava', ruski skovorodá itd.

18 Usp. Skok, s.v. skovrada: '2. čest toponim u otočkoj Dalmaciji', npr. otočić Škrovada kod Žirja. Usp. značenje u Anić, s.v. škrova (škrovada): 'cjediljka (za tjesteninu), šupljača'. Navodi se podrijetlo iz talijanskoga dijalekta, ali leksem s takvim značenjem nije pronađen. 
(Etymologický, s.v. skovrada). ${ }^{19}$ Oblik sličan potvrdi iz korpusa, s metatezom slogova va i ra, potvrđen je u staročeškom: skravada (usp. Fasmer 1971: 644). Početno š na mjestu $s$ može se pripisati interpretaciji govornika, odnosno lokalnoj izgovornoj prilagodbi pod mletačkim utjecajem.

U tvorbenom je smislu zanimljiv leksem lušija 'otopina za pranje dobivena kuhanjem pepela u vodi', čija je slavenska osnova lug, prema Skokovu tumačenju, ukrižena s dalmatoromanskim liksija (Skok, s.v. liksija).

Vrijedi istaknuti značenje leksema junak (50r) 'težak' (uz sinonim težak), koje nije zabilježeno u Rječnik 1880-1976.

Upozoriti treba i na odnose sinonimije u korpusu. Zanimljivi su slavensko-romanski sinonimni parovi: vodenica bevanda; zvaštano (vino) mufa; zdela terina; konj kavadun; stargulja rakatač/rakotaš 'ribež za sir'; ognjišće komin; ${ }^{20}$ nož pošada; korica bušta; zli, zločesti froli 'loš';1 harvaski ala šćavona. Leksem konj pojavljuje se u mlađem dijelu Inventara, od 1830., kako primjećuje priređivač u popisu manje poznatih riječi (Badurina 2013: 208). U slučaju ostalih parova nije zabilježena takva pravilnost u raspodjeli slavenskoga i romanskoga leksema, nego se oni izmjenjuju. Moguće je da su oba sinonima u paru slavenskoga podrijetla, npr. cipat polušat 'rezati' (uz imenicu kruh). Potonji glagol polušat, zanimljiv jer nije zabilježen u rječnicima, mogao bi se dovesti u vezu $\mathrm{s}$ glagolom (ras)polutiti ('raspoloviti'), odnosno pretpostaviti kao njegov nesvršeni parnjak. ${ }^{22}$ Slavensko-romanski sinonimni parovi koji se pojavljuju istovremeno (u istom popisu) očito upućuju na bliskoznačnost, a ne na istoznačnost: lonci lopiži, kopanjica konkula.

Mjestimice su sinonimi navedeni susljedno, tj. kontaktno. Evo nekih potvrda kontaktne sinonimije slavenskih parova: obaru aliti stražu (4r), obaru aliti prigledanje (6v), pod nastojanje aliti prigledanie $(11 \mathrm{v})$, brod aliti plav (6v). Pojava kontaktnih sinonima, koji u tekstu obično imaju svrhu

19 Leksem je u rumunjski mogao biti posuđen u praslavenskom razdoblju. Na njegovu starinu upućivao bi prije svega oblik bez metateze likvida, a isto tako i značenjski pomak tava $\rightarrow$ jelo iz tave (Mihăilă 1960: 60, 242).

20 Leksem komin potvrđen je samo jedanput (57r) jer je karakterističniji za područja izvan Dubašnice i Šotoventa (usp. Spicijarić Paškvan 2014a: 78).

21 Primjeri zao i zločest 'loš': intimel z merli dobrih i zlih (27r); vrić zločestih starih (6r), motike 4 zločeste (74v a). Značenje 'loš’ potvrđeno je u Rječnik 1880-1976.

22 'polučati (usp. polučak, 'mjera za žito' $\leftarrow$ polutak + jak; Skok, s.v. pol), sa /š/ kao rezultatom slabljenja, koje je doduše netipično jer je pred samoglasnikom. 
objašnjenja nepoznatih riječi (usp. Tafra 2018: 471), nameće pitanje - bez upuštanja u povijest svakoga pojedinog leksema - nije li i tu posrijedi očitovanje nadregionalne „standardizacijske” tendencije u razdoblju koje je prethodilo jezičnoj kodifikaciji (usp. Tafra 2018: 474).

\section{Zaključak}

U članku se donosi pregled jezičnih značajka spomenika pragmatične glagoljske pismenosti, Inventara samostana sv. Marije Magdalene u Portu na otoku Krku (1734. - 1878.). Prikazane su morfološke i morfosintaktičke osobitosti, sintaktičke značajke vezane uz atribut kao najzastupljeniju sintaktičku kategoriju te slavenski leksički elementi: terminologija vezana uz opremu crkve, kućanstvo, kuhinju, poljodjelstvo, stočarstvo i pomorstvo, pri čemu slavenski sloj prevladava samo u poljoprivrednoj terminologiji (posuđe, oruđe i pribor, kulture, proizvodi i postupci, stočarstvo).

Opća jezična slika Inventara, osobito njegova starijega dijela, upućuje kao i u fonologiji (Požar 2018b) na doseljeničke krčke govore kako su opisani u literaturi, suvremenoj (Lukežić, Turk 1998) i onoj vremenski bližoj istraživanomu izvoru (Milčetić 1895), naravno uz ogradu koja se tiče obilježenosti administrativnim stilom. Ipak, u mlađem dijelu Inventara, od kraja 18. stoljeća, zabilježene su inovacije koje nisu rezultat jezičnoga razvoja, nego uvođenja elemenata drugih čakavskih (a i ne samo čakavskih) dijalekata. To su nastavak -ov u genitivu množine a-deklinacije, srednji rod množine pridjeva različit od ženskoga, prezentski oblik počimle i zamjenica što. Iako bi se očekivalo da su te značajke odraz izraženije prisutnosti redovnika iz južnijih dijalektnih područja, povijesni izvori koji sadrže podatke o podrijetlu samostanskih članova ne potvrđuju znatniju zastupljenost štokavskih, južnočakavskih, pa čak ni južnijih srednjočakavskih govornika. Zbog toga se predlaže da se, po uzoru na zaključak u Botica, Kovačić, Kuhar (2015: 13), navedene inovacije pripišu obaviještenosti pojedinih pisara o široj uporabi hrvatskoga jezika krajem 18. stoljeća.

\section{Izvor}

Badurina, Anđelko (2013) Inventar samostana sv. Marije Magdalene u Portu na otoku Krku (1734. - 1878.), Glosa Rijeka i Provincijalat franjevaca trećoredaca glagoljaša Zagreb. 


\section{Literatura}

Anić, Vladimir (2003) Veliki rječnik hrvatskoga jezika, Novi liber, Zagreb.

Blažević Krezić, Vera (2016) Jezik Misala Dragutina Antuna Parčića, doktorska disertacija, Filozofski fakultet, Zagreb.

Boerio, Giuseppe (1867) Dizionario del dialetto veneziano [terza edizione aumentata e coretta], G. Cecchini, Venezia.

Boryś, Wiesław (2007) Čakavske leksičke studije: Praslavensko naslijeđe u čakavskome leksičkom fondu, preveo Nino Žodan, Matica hrvatska, Zagreb.

Botica, Ivan, Vinko Kovačić, Kristijan Kuhar (2015) Knjige posinovljenja, novicijata i zavjetovanja franjevaca trećoredaca glagoljaša otoka Krka (1717. - 1914.), Provincija franjevaca trećoredaca glagoljaša i Staroslavenski institut, Zagreb.

Etymologický slovník jazyka staroslověnského, 14, sice - srъdobolja; Doplňky k bibliografickému aparátu IV (2008), hlavní red. I. Janyšková, Academia, Praha.

Fasmer, Maks (1971) Etimologičeskij slovar' russkogo jazyka, perevod s nemeckogo i dopolnenija O. N. Trubačeva, tom III (Muza - Sjat), Izdatel'stvo Progress, Moskva.

Ivić, Milka (1954) Značenja srpskohrvatskog instrumentala i njihov razvoj (sintaksičko-semantička studija), Srpska akademija nauka, Beograd.

Lukežić, Iva, Marija Turk (1986) „Mjesni govor Milohnića”, Otok Krk: Zapadni dio. Krčki zbornik, 16 [Posebna izdanja Povijesnoga društva Krk 9], 231-253.

Lukežić, Iva, Marija Turk (1998) Govori otoka Krka, Libellus, Crikvenica.

Mihaljević, Ana, Jurica Polančec (2016) „Croatian non-standard invariant relativizers in European perspective”, Jezikoslovlje, 17/1-2, 429-451.

Mihăilă, Gheorghe (1960) Imprumuturi vechi sud-slave în limba română. Studiu lexico-semantic, Editura Academiei, București.

Milčetić, Ivan (1895) „Čakavština Kvarnerskih otoka”, Rad JAZU, 121, 92131.

Minlos, Philip (2012) „Slavic Relative čto / co: between Pronouns and Conjunctions", Slověne, 2012, 1, 74-91.

Požar, Sandra (2018a) „Čakavsko-romanski jezični dodir u Inventaru samostana sv. Marije Magdalene u Portu na otoku Krku (1734. - 1878.)”, Od 
fonologije do leksikologije: Zbornik u čast Mariji Turk, ur. Diana Stolac, Filozofski fakultet, Rijeka, 291-311.

Požar, Sandra (2018b) „Inventar samostana sv. Marije Magdalene u Portu na otoku Krku (1734. - 1878.) kao jezični izvor: grafija i fonologija", Fluminensia: časopis za filološka istraživanja, 30, 2, 29-43.

Rječnik hrvatskoga ili srpskoga jezika (1880-1976), ur. Đ. Daničić, M. Valjavec, P. Budmani, T. Maretić, S. Musulin, S. Pavešić, JAZU, Zagreb.

Skok, Petar (1971-1974) Etimologijski rječnik hrvatskoga ili srpskoga jezika, I-IV, uredili M. Deanović i Lj. Jonke, JAZU, Zagreb.

Spicijarić Paškvan, Nina (2014a) „Dalmatski (veljotski) i mletački utjecaji u govorima otoka Krka”, Krčki zbornik, 70, 71-88.

Spicijarić Paškvan, Nina (2014b) „Vlasi i krčki Vlasi u literaturi i povijesnim izvorima", Studii şi cercetări - Actele Simpozionului "Banat - istorie şi multiculturalitate” / Studije i istraživanja - Radovi Simpozijuma „Banat - istorija i multikulturalnost” - Zrenianin 2012 şi Reşița 2013 / Zrenjanin 2012 i Rešica 2013, red. C. Roşu, N. Ciobanu, Institutul de Cultură al Românilor din Voivodina, Zrenjanin, 345-358.

Štefanić, Vjekoslav (1960) Glagoljski rukopisi otoka Krka, Jugoslavenska akademija znanosti i umjetnosti, Zagreb.

Tafra, Branka (2018) „Leksičko-semantički odnosi u hrvatskom jeziku iz dijakronijske perspektive", Leksikologija i leksikografija slavjanskih jazykov, red. M. I. Černyševa, LEKSRUS, Moskva, 465-487.

Vela, Jozo (2019) „Hrvatski za-infinitiv: izvanjsko posuđivanje ili unutarnji jezični razvoj”, Fluminensia: časopis za filološka istraživanja, 31, 1, 61-83.

Vince, Jasna (2014) „Imenice”, Hrvatski crkvenoslavenski jezik, prir. M. Mihaljević, Hrvatska sveučilišna naklada i Staroslavenski institut, Zagreb, 91-132. 


\section{SUMMARY}

Sandra Požar

MORPHOLOGICAL, SYNTACTIC AND LEXICAL FEATURES OF THE GLAGOLITIC INVENTORY OF THE MONASTERY OF ST. MARY MAGDALENE IN PORAT ON THE ISLAND OF KRK (1734 - 1878)

In this paper we describe linguistic features of the Inventory of St. Mary Magdalene in Porat on the island of Krk (1734-1878), one of the testaments to the pragmatic Glagolitic literacy: its morphological features, syntactic features of the attribute as the most frequent syntactic category, and its Slavic lexical elements - terminology mainly related to agriculture, livestock and fishery. The recorded phenomena were compared with the descriptions of the Krk dialects in literature: the one that describes the present state (Lukežić, Turk 1998) and the one that is almost contemporary to the Inventory itself (Milčetić 1895). The general linguistic picture of the Inventory, especially its older part, is congruent with the immigrant dialects of the island of Krk, differing mainly in that it is marked by the administrative style.

However, in the later part of the Inventory, starting from the end of the $18^{\text {th }}$ century, some innovations can be noted, not as a result of linguistic development, but as a result of the introduction of elements of other Čakavian, and even Štokavian dialects: the genitive plural ending -ov of the a-declension, plural neuter adjective form different from the one for the feminine gender, the present form počimle, the pronoun što. Although it might be assumed that these innovations originated from the speakers of the respective dialects, historical sources containing information on the origin of monastic members, which were published recently, do not confirm this hypothesis. For this reason, the innovations should perhaps be attributed to the awareness of individual scribes of a wider usage of the Croatian language at the end of the $18^{\text {th }}$ century.

Key words: Glagolitic script; Glagolitic friars of the Franciscan Third Order Regular; pragmatic Glagolitic literacy; history of the Croatian language; Cakavian dialect; dialects of the island of Krk 